\title{
Gamma-Interferon-Inducible Protein 16
}

National Cancer Institute

\section{Source}

National Cancer Institute. Gamma-Interferon-Inducible Protein 16. NCI Thesaurus. Code C115028.

Gamma-interferon-inducible protein 16 (785 aa, $~ 88 \mathrm{kDa}$ ) is encoded by the human IFI16 gene. This protein plays a role in both immune response-mediated programmed cell death and transcriptional regulation. 